\title{
REINVESTIGATIONS OF THE RELATIONSHIP BETWEEN SPORULATION, HEAT RESISTANCE AND SOME BIO- CHEMICAL PROPERTIES IN STRAINS OF CLOSTRIDIUM PERFRINGENS
}

\author{
S. NAKAMURA AND S. Nishida \\ Department of Bacteriology, School of Medicine, Kanazawa University, Kanazawa, Japan
}

IN a previous paper (Nishida, Seo and Nakagawa, 1969) we demonstrated that heat selection was one of the main elements to give rise to or to demonstrate diversity in the biological properties of Clostridium perfringens; salicinfermenting and gelatinase-negative strains of $C$. perfringens were frequently isolated from soil samples preheated at $100^{\circ} \mathrm{C}$ for 1 hour or more. We recently found that there appeared to be concurrent variation in some other properties of isolates obtained from heated samples. In the present investigation we attempt to establish a correlation between the concurrent conversion of biochemical properties and conditions for preheating in studies with a number of $C$. perfringens isolates. In the course of these studies, it was proved that sporulation of these organisms frequently occurs in the presence of a slowly fermentable sugar. This finding led us to a further study of the effects of sugars on sporulation of $C$. perfringens.

\section{MATERIALS AND METHODS}

Strains. A total of 94 strains of $C$. perfringens was used in this study. Most of the strains were newly isolated from soil according to the method described by Yamagishi, Ishida and Nishida (1964). The soil samples were collected from places at least 50 metres apart in the vicinity of our Medical School. One isolate was taken from one soil sample. Typing of these isolates was not performed. Fourteen stock strains (Nishida et al., 1969) were also used.

Biochemical tests. Routine biochemical tests were performed according to Sterne and van Heyningen (1965). All cultures were incubated for 1 week anaerobically in $\mathrm{H}_{2}$ in an anaerobic jar (Tominaga Ltd, Tokyo, Japan) with Deoxo pellets (Baker Platinum Ltd, London) as the catalyst; the cultures were then examined for their biochemical properties. Hydrolysis of aesculin was detected by adding 2-3 drops of $1 \%$ ferric ammonium citrate solution to the culture. Hydrolysis of arbutin was detected by adding $0.5 \mathrm{ml} 2 \mathrm{M}$ sodium carbonate solution to a $1-\mathrm{ml}$ volume of the culture and standing the mixture at room temperature for $60 \mathrm{~min}$. Development of a black colour was recorded as a positive result in both cases.

Sporulation medium. The medium of Duncan and Strong (1968) was used (D-S medium). To examine effects of sugars on sporulation, $0.4 \mathrm{ml}$ of a $10 \%$ Seitz-filtered solution of the test sugar was added to a $10-\mathrm{ml}$ volume of $\mathrm{D}-\mathrm{S}$ medium without starch and the following procedure was performed. An active culture was obtained by overnight growth of each strain in $10 \mathrm{ml}$ Fluid Thioglycollate Medium (FTG; Nissan Co., Tokyo, Japan). Two subsequent serial transfers into $10-\mathrm{ml}$ volumes of fresh FTG, with a $10 \%$ inoculum and a 4-hour incubation period at $37^{\circ} \mathrm{C}$, were then made. A $1-\mathrm{ml}$ volume of the last culture was inoculated into $10 \mathrm{ml} \mathrm{D}$-S medium that had been boiled and cooled immediately before use, and this

Received 23 Jan. 1974; accepted 27 Feb. 1974.

J. MED. MICROBIOL.- VOL. 7 (1974) 
culture was incubated at $37^{\circ} \mathrm{C}$ for 40 hours, when the sporulating frequency was determined. These cultures in D-S and FTG media were not incubated in an anaerobic jar.

Determination of sporulating frequency. This was estimated by two different methods.

1. Viable counts before and after pasteurisation. The total number of colony-forming units (viable count, V) in a culture was determined by plating $0 \cdot 1-\mathrm{ml}$ volumes of serial ten-fold dilutions of the culture in $0.85 \% \mathrm{NaCl}$ solution on Brain-Heart Infusion Agar (Nissan Co., Tokyo, Japan) supplemented with $1 \%$ glucose. The total spore population (S) was determined by the same procedure after heating the culture at $75^{\circ} \mathrm{C}$ for $15 \mathrm{~min}$. Plates were incubated anaerobically in $\mathrm{H}_{2}$ at $37^{\circ} \mathrm{C}$ for 40 hours. The sporulation frequency was recorded as the ratio $\mathrm{S} / \mathrm{V}$.

2. Enumeration of cells and spores by microscopy. A portion of the culture was centrifuged and a smear of the sediment was stained by the method of Wirtz (1908). Bacterial cells and green spores in a microscopic field were enumerated; at least 1000 cells were counted and the sporulation frequency was measured as the ratio of the number of spores to the total cell count.

\section{RESULTS}

In a preliminary experiment, seven $C$. perfringens strains from each of two groups, (i) strains isolated from unheated soil samples (unheated group), and (ii) strains from those heated at $100^{\circ} \mathrm{C}$ for $60 \mathrm{~min}$. (100-60 group), were examined for their ability to ferment the following 14 carbohydrates: cellobiose, dextrin, fructose, galactose, glucose, inositol, lactose, mannose, maltose, melibiose, raffinose, salicin, sucrose and starch. Distinct differences between the two groups could be found only in the fermentation of salicin, cellobiose and inositol; all strains of the unheated group fermented inositol, but none fermented salicin and cellobiose, whereas all strains of the 100-60 group fermented salicin and cellobiose, but none attacked inositol.

Further experiments were undertaken to establish a correlation between strains isolated by a heating procedure and the ability to ferment salicin, cellobiose and inositol. Soil samples were heated at 70,90 and $100^{\circ} \mathrm{C}$ for 10 min., and at $100^{\circ} \mathrm{C}$ for $1,2,3$ and 5 hours respectively. A total of $80 \mathrm{C}$. perfringens isolates were obtained from soil samples in this way. The longer the preheating, the greater the number of isolates that fermented salicin and cellobiose. No isolate from samples heated at $100^{\circ} \mathrm{C}$ could ferment inositol, although all of the unheated group could ferment inositol. Out of 50 isolates from samples heated at $100^{\circ} \mathrm{C}, 28$ fermented both salicin and cellobiose, only 3 fermented salicin or cellobiose alone, and the remaining 19 fermented neither (table I).

We further investigated the sporulating abilities of isolates that had been subjected to heat treatment at $100^{\circ} \mathrm{C}$ for more than 1 hour; a total of $27 \mathrm{C}$. perfringens strains belonging to groups VI, VII and VIII (table I) were used. The results shown in table II indicate that the longer the period of preheating at $100^{\circ} \mathrm{C}$, the weaker the sporulating abilities of the isolates. The findings summarised in tables I and II suggest a close correlation between attenuation of sporulating ability and the above-mentioned fermentation patterns. When the 27 isolates of groups VI, VII and VIII (table I) were graded according to their sporulating abilities and examined for their fermentation of cellobiose and salicin, a very clear correlation emerged (table III). 
Salicin and cellobiose both have a $\beta$-glucoside bond in their structures. We accordingly tested the cellobiose- and salicin-positive strains for their

TABLE I

Effects of preheating* on biochemical properties of Clostridium perfringens isolates

\begin{tabular}{|c|c|c|c|c|c|c|}
\hline \multirow[b]{2}{*}{ Group } & \multirow[b]{2}{*}{$\begin{array}{c}\text { Preheating } \\
\text { exposure }\end{array}$} & \multicolumn{5}{|c|}{ Number of } \\
\hline & & $\begin{array}{l}\text { isolates } \\
\text { used }\end{array}$ & $\begin{array}{l}\text { cellobiose- } \\
\text { and } \\
\text { salicin- } \\
\text { positive } \\
\text { isolates }\end{array}$ & $\begin{array}{l}\text { cellobiose- } \\
\text { positive } \\
\text { and } \\
\text { salicin- } \\
\text { negative } \\
\text { isolates }\end{array}$ & $\begin{array}{l}\text { cellobiose- } \\
\text { negative } \\
\text { and } \\
\text { salicin- } \\
\text { positive } \\
\text { isolates }\end{array}$ & $\begin{array}{l}\text { inositol- } \\
\text { positive } \\
\text { isolates }\end{array}$ \\
\hline I & none & 10 & 0 & 1 & 1 & 10 \\
\hline II & $70^{\circ} \mathrm{C}$ & 10 & 0 & 0 & 2 & 7 \\
\hline III & $90^{\circ} \mathrm{C}$ & 10 & 2 & 0 & 0 & 6 \\
\hline IV & $\begin{array}{l}\text { for } 10 \mathrm{~min} . \\
100^{\circ} \mathrm{C}\end{array}$ & 9 & 3 & 0 & $\mathbf{0}$ & 0 \\
\hline V & $\begin{array}{l}\text { for } 10 \mathrm{~min} \text {. } \\
100^{\circ} \mathrm{C}\end{array}$ & 14 & 5 & 1 & 1 & 0 \\
\hline VI & $\begin{array}{l}\text { for 1 hour } \\
100^{\circ} \mathrm{C}\end{array}$ & 10 & 6 & 0 & 1 & 0 \\
\hline VII & $\begin{array}{l}\text { for } 2 \text { hours } \\
100^{\circ} \mathrm{C}\end{array}$ & 10 & 7 & 0 & 0 & 0 \\
\hline VIII & $\begin{array}{l}\text { for } 3 \text { hours } \\
100^{\circ} \mathrm{C} \\
\text { for } 5 \text { hours }\end{array}$ & 7 & 7 & 0 & 0 & 0 \\
\hline
\end{tabular}

* This denotes that a heat treatment of a soil sample was used for the isolation of the organism.

TABLE II

Effects of heat treatment of soil samples on sporulating abilities of isolates therefrom

\begin{tabular}{|c|c|c|c|c|}
\hline \multirow{2}{*}{$\begin{array}{l}\text { Heat- } \\
\text { treatment } \\
\text { group* }\end{array}$} & \multirow{2}{*}{$\begin{array}{c}\text { Number of } \\
\text { isolates } \\
\text { used }\end{array}$} & \multicolumn{3}{|c|}{$\begin{array}{c}\text { Number of isolates with a sporulation frequency } \dagger \text { of } \\
\text { more than }\end{array}$} \\
\hline & & $0.1 \%$ & $0.09-0.01 \%$ & $0.009-0.001 \%$ \\
\hline VI & 10 & 4 & 2 & 4 \\
\hline VII & 10 & 3 & 1 & 6 \\
\hline VIII & 7 & 0 & 0 & 7 \\
\hline
\end{tabular}

* Grouping according to conditions of preheating of soil sample (see table I).

$\uparrow$ Measured by a viable count procedure (see Methods); the sporulation medium was that of Duncan and Strong (1968).

ability to attack two other sugars, aesculin and arbutin, that have a $\beta$-glucoside bond. Eighteen strains each of salicin- and cellobiose-positive and salicin- and cellobiose-negative $C$. perfringens strains were selected from our collection; all were isolated from soil samples heated for 1 hour or more. The results given 
in table IV show that all strains of the former group hydrolysed aesculin and arbutin, whereas none of the latter group hydrolysed the two glucosides.

TABLE III

Relationship between sporulation frequency and fermentation of cellobiose and salicin

\begin{tabular}{c|cc}
\hline $\begin{array}{c}\text { Grade of } \\
\text { sporulation* }\end{array}$ & $\begin{array}{c}\text { Number of } \\
\text { isolates } \\
\text { used }\end{array}$ & $\begin{array}{c}\text { Number of cellobiose- } \\
\text { and salicin-positive } \\
\text { isolates }\end{array}$ \\
\hline+ & 7 & 0 \\
\pm & 3 & 0 \\
- & 17 & 17 \\
\hline
\end{tabular}

*Sporulation frequency was determined by a viable count procedure; the following scoring system was used: $t=>0.1 \% ; \pm=0.09-0.01 \% ;-=<0.009 \%$.

We then examined the influence of various sugars on sporulation. In a preliminary study with two strains of $C$. perfringens, the effects of 9 sugars, namely glucose, maltose, fructose, lactose, sucrose, salicin, raffinose, melibiose and starch, were examined. Raffinose and melibiose appeared to promote sporulaion, but other sugars were ineffective and starch was relatively ineffective. Table $\mathrm{V}$ gives the results of a detailed study of the effects of raffinose,

TABLE IV

Difference in hydrolysis of aesculin and arbutin between cellobiose- and salicin-positive and cellobiose- and salicin-negative isolates

\begin{tabular}{lccc}
\hline $\begin{array}{l}\text { Category } \\
\text { of isolate }\end{array}$ & $\begin{array}{c}\text { Number of } \\
\text { isolates used }\end{array}$ & $\begin{array}{c}\text { Number (and percentage) of isolates } \\
\text { hydrolysis-positive for }\end{array}$ \\
\hline $\begin{array}{l}\text { Cellobiose- and } \\
\text { salicin-positive }\end{array}$ & 18 & $18(100)$ & $18(100)$ \\
$\begin{array}{l}\text { Cellobiose- and } \\
\text { salicin-negative }\end{array}$ & 18 & $0(0)$ & $0(0)$ \\
\hline
\end{tabular}

melibiose and starch in tests with 21 isolates of $C$. perfringens from samples exposed to different conditions of preheating. These data confirm that raffinose and melibiose influence sporulation of these strains under the conditions of our tests. The findings also indicate further differences in behaviour of isolates from samples heated at $100^{\circ} \mathrm{C}$ and isolates from samples heated at less than $100^{\circ} \mathrm{C}$. None of the isolates from samples preheated at $100^{\circ} \mathrm{C}$ sporulated in the sugar-free D-S medium although most of them could still sporulate in the presence of melibiose and raffinose, and less markedly in the presence of starch. 
However, most of the isolates recovered from samples preheated at less than $100^{\circ} \mathrm{C}$ sporulated in the sugar-free medium and their sporulation was enhanced by melibiose and raffinose but depressed by starch.

\section{Discussion}

Bergey's manual (Breed, Murray and Smith, 1957) records that C. perfringens rarely ferments salicin; there is no comment on the utilisation of cellobiose or the hydrolysis of aesculin and arbutin by this species. The present

TABLE V

Effect of various sugars on sporulation of $C$. perfringens

\begin{tabular}{|c|c|c|c|c|c|}
\hline \multirow{2}{*}{$\begin{array}{l}\text { Isolate } \\
\text { number }\end{array}$} & \multirow{2}{*}{$\begin{array}{l}\text { Conditions of } \\
\text { heating used } \\
\text { for isolation }\end{array}$} & \multicolumn{4}{|c|}{ Sporulation frequency (percentage)* in the presence of } \\
\hline & & melibiose & raffinose & starch & no carbohydrate \\
\hline $\begin{array}{r}6 \\
7 \\
8 \\
9 \\
12 \\
14 \\
15 \\
16 \\
18\end{array}$ & $70^{\circ} \mathrm{C}, 10 \mathrm{~min}$ & $\begin{array}{c}-\dagger \\
7.8 \\
11.2 \\
- \\
- \\
5.8 \\
6.0 \\
6.9 \\
12.1\end{array}$ & $\begin{array}{l}- \\
3 \cdot 1 \\
4 \cdot 7 \\
- \\
- \\
3 \cdot 2 \\
5 \cdot 4 \\
9 \cdot 0 \\
3 \cdot 6\end{array}$ & $\begin{array}{l}\overline{0.2} \\
= \\
= \\
\overline{-} \\
\overline{-} \\
-\end{array}$ & $\begin{array}{l}0.6 \\
7.2 \\
1.2 \\
1.8 \\
- \\
0.5 \\
\overrightarrow{3.0} \\
9.7\end{array}$ \\
\hline $\begin{array}{r}112-4 \\
22 \\
23 \\
25 \\
35 \\
36 \\
38 \\
40 \\
44 \\
45 \\
47 \\
55\end{array}$ & $\begin{array}{l}100^{\circ} \mathrm{C}, 10 \text { min. } \\
100^{\circ} \mathrm{C}, 1 \text { hour } \\
100^{\circ} \mathrm{C}, 2 \text { hours } \\
100^{\circ} \mathrm{C}, 3 \text { hours } \\
100^{\circ} \mathrm{C}, 5 \text { hours }\end{array}$ & $\begin{array}{r}3 \cdot 8 \\
38 \cdot 0 \\
0 \cdot 7 \\
1 \cdot 7 \\
-\overline{0} \\
0 \cdot 7 \\
- \\
\overline{-} \\
29 \cdot 0 \\
10 \cdot 8 \\
26 \cdot 9 \\
-\end{array}$ & $\begin{array}{c}1 \cdot 3 \\
24 \cdot 0 \\
30 \cdot 3 \\
= \\
\overline{-} \\
12 \cdot 8 \\
1 \cdot 9 \\
- \\
8 \cdot 7 \\
9 \cdot 6 \\
=\end{array}$ & $\begin{array}{l}-\overline{0.1} \\
1 \cdot 3 \\
- \\
\overline{0} \\
= \\
= \\
\overline{0} \\
-9 \\
-\end{array}$ & $\begin{array}{l}\overline{-} \\
= \\
= \\
= \\
= \\
= \\
= \\
= \\
=\end{array}$ \\
\hline
\end{tabular}

* Sporulation frequency was determined microscopically (see Methods).

$\dagger-=<0 \cdot 1 \%$.

study confirms that strains that can ferment salicin, cellobiose or arbutin are rarely isolated from unheated soil samples or from samples heated at less than $100^{\circ} \mathrm{C}$, although more than half of these strains were able to hydrolyse aesculin. It was found that the longer the preheating of soil samples at $100^{\circ} \mathrm{C}$, the greater the number of isolates that could attack all four of these carbohydrates.

Two hypotheses may be postulated to account for the appearance of strains with these variations in which heat resistance-as judged by survival of a preheating step during their isolation-appears to be paradoxically related to attenuated sporulating ability and to extended fermentation ability. Attenuated sporulating abilities of strains recovered from samples heated at $100^{\circ} \mathrm{C}$ for more than 1 hour give rise to a prolonged vegetative stage of the organism and, 
consequently, (i) their normally undetectable enzyme activities may be expressed, or (ii) the frequency of the appearance of mutants that can attack these carbohydrates may be increased. Our recent findings suggest that the second postulate is the more reasonable. However, the genetic or biochemical process whereby this biochemical diversity is expressed remains to be determined and the apparent difference in heat resistance of the two groups is unexplained.

Most of the sugars tested inhibited sporulation of $C$. perfringens, although these sugars enhanced growth. The present study reveals, however, that $C$. perfringens could sporulate in the presence of some slowly fermented sugars more abundantly than in the absence of sugars or in the presence of rapidly fermented sugars. Ellner (1956), and Duncan and Strong (1968) employed starch, and Ellner recommended raffinose for a sporulation medium although he did not give any data on this. We have found that melibiose and raffinose may promote more reproducible sporulation than starch, a commercial product that usually differs in its properties according to the material from which it was prepared. We examined three kinds of starch prepared from respectively wheat, potato or corn (Wako, Tokyo, Japan) but none was effective in promoting sporulation of $C$. perfringens.

Nishida et al. (1969) stated that strains of $C$. perfringens in the 100-60 group were definitely weaker in their sporulating ability than the strains of the unheated group; these observations were based on studies with Nishida and Seo's medium (Nishida et al., 1969) which did not include any sugar. Our present findings in studies with the sugar-free medium of Duncan and Strong (1968) support that view, but disclose that most of the heat-treated strains could still sporulate in the medium containing raffinose or melibiose.

\section{SUMMARY}

Isolates of Clostridium perfringens obtained from soil samples heated at $100^{\circ} \mathrm{C}$ and from samples heated at less than $100^{\circ} \mathrm{C}$ exhibited markedly different fermentation properties in tests with inositol, salicin, cellobiose, arbutin and aesculin. None of the $C$. perfringens isolates obtained from samples heated at $100^{\circ} \mathrm{C}$ for various lengths of time could ferment inositol, whereas all of the isolates obtained from unheated samples could ferment this sugar. The longer the preheating period at $100^{\circ} \mathrm{C}$, the greater the number of aberrant isolates that attacked salicin, cellobiose, aesculin and arbutin, and the weaker were the sporulating abilities of these isolates. Most of the " heat-resistant" strains with attenuated sporulating abilities, however, could sporulate well when raffinose or melibiose was the only carbohydrate present in a test medium.

We wish to thank Dr C. T. Huang for helpful comments and Dr J. G. Collee for instructive discussion.

\section{REFERENCES}

Breed, R. S., MurRay, E. G. D. ANd SMIth, N. R. 1957. In Bergey's Manual of determinative bacteriology, 7th ed., Baltimore, p. 666.

DunCAN, C. L. AND STRONG, D. H. 1968. Improved medium for sporulation of Clostridium perfringens. Appl. Microbiol., 16, 82. 
EllNeR, P. D. 1956. A medium promoting rapid quantitative sporulation in Clostridium perfringens. J. Bact., 71, 495.

Nishida, S., Seo, N. ANd NaKagawa, M. 1969. Sporulation, heat resistance and biological properties of C. perfringens. J. appl. Bact., 17, 303.

Sterne, M. and van Heyningen, W. E. 1965. The Clostridia. In Bacterial and mycotic infections of man, 4th ed., edited by R. J. Dubos and J. G. Hirsh, Philadelphia, p. 545.

Wirtz, R. 1908. Eine einfache Art der Sporenfärbung. Zentbl. Bakt. Parasitkde, I Abt. Orig., 46, 727.

YAMAGISHI, T., IsHidA, S. AND NISHIDA, S. 1964. Isolation of toxigenic strains of Clostridium perfringens from soil. J. Bact., 88, 646. 